\title{
Pemanfaatan Beluntas (Pluchea indica (L.) Less) dan Bioaktivitasnya (Kajian Lanjutan Pemanfaatan Tumbuhan dari Pengabdian Kepada Masyarakat di Desa Sindang Jaya, Kabupaten Cianjur)
}

\author{
Marina Silalahi ${ }^{*}$ \\ ${ }^{1}$ Prodi Pendidikan Biologi FKIP, Universitas Kristen Indonesia, Jakarta. \\ *marina_biouki@yahoo.com; marina.silalahi@uki.ac.id
}

\begin{abstract}
ABSTRAK
Pluchea indica (PI) atau beluntas telah lama dimanfaatkan sebagai obat, sayur dan minuman kesehatan oleh berbagai masyarakat khususnya di Asia Tenggara termasuk masyarakat di Desa Sindang Jaya Cianjur. Pemanfaatan PI sebagai obat tradisional berhubungan dengan kandungan metabolit sekundernya. Penulisan artikel ini didasarkan pada kajian literatur yang bersumber dari jurnal ilmiah, buku maupun hasil penelitian yang berhubungan dengan pemanfaatan dan bioaktivitas PI. Masyarakat di Desa Sindang Jaya memanfaatkan PI sebagai lalaban (sayur) dan juga obat sehingga mudah ditemukan di lingkungan sekitar terutama pekaranagn. Secara etnobotani PI dimanfaatkan untuk mengatasi diabetes mellitus, tumor, hipertensi, sistitis, luka, tonik otak, batu ginjal, wasir, radang, sakit pinggang, keputihan, lumbago, ulcer, tuberculosis dan inflammasi. Berbagai senyawa aromatik ditemukan pada PI seperti thiophenes, asam klorogenat, asam 3,4-O-dicaffeoylquinic, dan asam 3,5-Odicaffeoylquinic. Senyawa tiofena memiliki sifat biologis yang luas seperti antimikroba, anti virus, inhibitor HIV-1 protease, anti leishmania, nematisidal, insektisidal, fototoksik dan anti kanker. Bioaktivitas PI sebagai anti mikroba, antioksidan, anti fertilitas, anti diabetes mellitus, anti inflamantori, analgesik, anti kanker dan obat luka. Pemanfaatan PI sebagai antiobesitas perlu dikaji lebih lanjut sehingga dapat dikembangkan sebagai bahan pangan menyehatkan sekaligus menurunkan berat badan.
\end{abstract}

Kata kunci: Pluchea indica, anti fertilitas, anti obesitas, tiofene

\section{PENDAHULUAN}

Pemanfaatan tumbuhan sebagai obat untuk menunjang kesehatan telah lama dilakukakan dan terus meningkat seiring dengan perkembangan ilmu pengetahuan dan teknologi. Walaupun telah banyak dilaporkan tumbuhan bermanfaat obat, namun kegiatan penelitian eksplorasi tumbuhan obat terus ditingkatkan terutama untuk mendapatkan senyawa baru yang dapat digunakan untuk mengatasi penyakit yang sulit disembuhkan seperti kanker, stroke, dan diabetes mellitus. Beberapa obat alami yang berasal dari tumbuhan diperkenalkan pasar Amerika Serikat, seperti arteether, galantamine, nitisinone, dan tiotropium (Balunas and Kinghorn, 2005).

Asteraceae merupakan salah satu famili yang banyak digunakan sebagai obat seperti Ageratum conyzoides, Gynura pseudochina, dan Pluchea indica. Pluchea indica (PI) atau beluntas dimanfaatkan sebagai obat dan sayur (Raharjo dan Horsten, 2002). Tumbuhan ini mudah ditemukan di berbagai pekarangan etnis Sunda karena memiliki fungsi ganda yaitu sebagai obat, tanaman hias dan tanaman pangan (Silalahi, 2019). Dalam pengobatan tradisional PI dimanfaatkan untuk mengatasi diare, demam (Raharjo dan Horsten, 2002), dan tonik saraf (Kongkiatpaiboon et al., 2018). 
VIVABIO

Jurnal Pengabdian Multidisiplin

Pemanfaatan tumbuhan sebagai obat secara langsung maupun tidak langsung berhubungan dengan senyawa bioaktifnya. Hasil skreening fitokimia genus Pluchea mengandung berbagai metabolit sekunder seperti flavonoid, tannin, alkaloid, jenis eudesmane, sesquiterpenoid, monoterpen, glikosida lignan dan triterpenoid (Ahemd and Kamel, 2013). Metabolit sekunder dalam bidang pengobatan memiliki aktivitas yang berbeda beda. Sebagai contoh flavonoid dan fenolik dihubungkan dengan aktivitas sebagai antioksidan. Komsumsi daun PI sebagai ramuan kuliner dapat meningkatkan kesehatan karena mengandung serat makanan, kalsium, $\beta$-karoten, asam klorogenat, asam kafeat dan quercetin (Suriyaphan, 2014).

PI juga digunakan sebagai sayuran dengan cara dilalap atau dimasak yaitu bagian daun muda, pucuk maupun bunga (Raharjo dan Horsten, 2002). Teh herbal PC telah dikomersialkan di Thailand sebagai minuman untuk meningkatkan kesehatan (Chewchinda and Vongsak, 2018). Pluchea merupakan tanaman yang sangat heterogen (Raharjo dan Horsten, 2002), oleh karena itu perlu pemahaman dari segi botaninya untuk memastikan ketepatan bahan tumbuhan yang digunakan. Ketepatan bahan merupakan salah satu faktor yang sangat berpengaruh terhadap khasiatnya.

Widyawati et al. (2013) menyatakan bahwa kandungan esensial oil pada PI mirip dengan kemangi (Ocimum basilicum) dan kadar senyawa fenolnya lebih tinggi dibandingkan dengan $O$. basilicum yang memiliki aktivitas sebagai antioksidan. Walaupun telah terbukti memiliki kadar essesial oil dan fenol yang baik bagi kesehatan, namun bagi masyarakat lokal Indonesia pemanfaatannya PI kurang familiar bila dibandingkan dengan $O$. basilicum, oleh karena itu perlu informasi untuk menjelaskan botani, manfaat, metabolit sekunder, serta bioaktivitas dari PI. Secara empirik terlihat bahwa masyarakat etnis Sunda di Desa Sindang Jaya, Cianjur telah lama memanfaatkannya sebagai lalaban (sayur) dan juga sebagai obat. Artikel ini bertujuan untuk menjelaskan botani, manfaat dan senyawa bioaktif dari PI sehingga dapat digunakan sebagai informasi untuk dasar pemanfaatan dan pengem-bangannya sebagai obat tradisional, pangan dan obat modern.

\section{METODE PELAKSANAAN}

Penulisan artikel ini diawali dengan pengabdian kepada masyarakat di Desa Sindang Jaya Cianjur tentang pemanfaatan tumbuhan. Pluhea indica merupakan salah satu tumbuhan yang digunaksan masyarakat setempat sebagai sayur atau lalaban dan obat. Untuk memberi informasi yang lebih konfrehensif tentang PI dilakukan studi literature terhadap berbagai artikel atau penelitian yang telah terpublish secara on line maupun off line. On line didasarkan pada hasil penelitian berupa tesis, disertasi, dan juga artikel atau jurnal ilmiah, google schoolar. Beberapa kata kunci yang digunakan adalah Plucea indica, secondary metabolites dan bioactivities of Pluchea indica. Semua artikel yang disintesakan sehingga diperoleh informasi yang konfrehensif tentang botani, manfaat dan senyawa bioaktif PI.

\section{HASIL DAN LUARAN YANG DICAPAI \\ 1. BOTANI Pluchea indica (L.) Less}

Asteraceae merupakan famili yang sangat besar dengan memiliki sekitar 1.6001.700 genus dan 24.000-30.000 species (Ruan et al., 2018). Genus Pluchea merupakan salah satu genus dalam famili 
VIVABIO

Jurnal Pengabdian Multidisiplin

Asteraceae dengan sekitar 40 species (Raharjo dan Horsten, 2002) - 90 species (Ahemd dan Kamel 2013), yang terdistribusi terutama di Amerika Utara dan Selatan, Afrika, Asia, dan Australia (Ahemd dan Kamel 2013). Pluchea indica (PI) telah lama dimanfaatkan untuk berbagai tujuan sebagai bahan pangan, obat, maupun tanaman hias (Silalahi 2019). Pluchea indica (L.) Less sinonim dengan Pluchea foliosa DC. (1831) (Raharjo dan Horsten, 2002). Vernaculer name PI antara lain: indian pluchea (Inggris), beluntas (Indonesia, Malaysia), luntas (Jawa), baruntas (Sunda), kalapini (Tagalog), baingbaing (sulu), khlu (Thailand), lat nuat (laos). Pluchea indica ditemukan dari India ke China bagian Selatan, Indochina, Thailand, Malaysia, Indonesia, Australia dan pulau pulau Pasific (Raharjo dan Horsten, 2002).

Ciri-ciri PI merupakan tanaman perdu yang selalu hijau dengan tinggi $1-3 \mathrm{~m}$, ramping dan memiliki banyak cabangcabang. Cabang berbentuk silindris dan berkayu, bewarna coklat tua dan warna hijau dibagian ujung, glabrous (tidak memiliki rambut-rambut atau halus). Daun berupa daun tunggal dan bersusun berselang-seling, berbentuk ovate hingga obovate, dengan ukuran 2,5-8 cm x 1-5 cm, bagian basal attenuate dan agian ujung acuminate, tepi daun serrate, kelenjar tidak jelas pada kedua permukaan daun, dan ketika diremas mengeluarkan bau aromatis. Tangkai daun pendek atau subsesil dan tidak memiliki stipula. Pembungaan memiliki beberapa kepala dengan bentuk hemisphere dibagian ujung atau axylary corymb atau panicula dengan lebar 2,5-12,5 cm (Gambar 1). Peduncula pendek dengan bractea memebentuk involucrum dengan 6-7 seriate dan dibagian luar berbentuk bulat telur. Semua bunga berbentuk tubuler dan bagian tepi adalah bunga betina dengan panjang corolla 3,5-5 cm, bunga dibagian tengan 2-6 biseksual dengan stamina yang fungsional dan corolla berbentuk filiform. Antera berjumlah 5 dan ovarium inferior. Buah berbentuk silinder dengan buah achene, dengan panjang $1 \mathrm{~cm}$, halus dengan rusuk 5 , bewarna coklat. Perkecambahan bersifat epigeal (Raharjo dan Horsten, 2002).

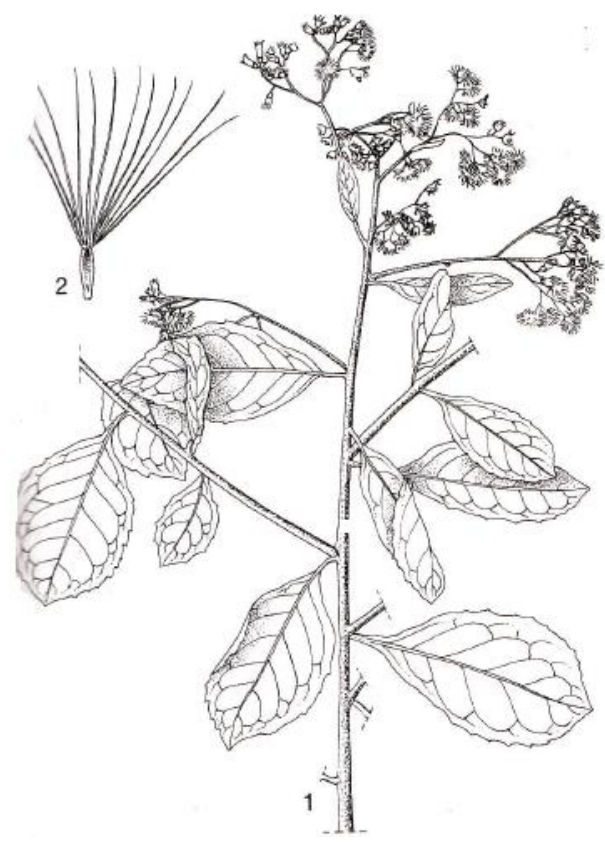

Gambar 1. Pluchea indica L. Less 1. Cabang yang berbunga 2. Achene (Raharjo dan Horsten, 2002).

\section{METABOLIT SEKUNDER}

Metabolit sekunder merupakan senyawa yang dihasilkan tumbuhan dari proses metabolisme sekunder. Jenis dan kadar metabolit sekunder tumbuhan sangat beragam, namun aktivitasnya sebagian besar dihubungkan dengan pertahanan dan adaptasi tumbuhan terhadap lingkungan sekitar (Taiz and Zeiger, 2006). Manusia metabolit sekuder digunakan untuk pengobatan, pewarna, insektisida, dan juga aroma terapi, namun pemanfaatannya sebagai obat lebih menonjol dibandingkan yang lainnya. 
VIVABIO

Jurnal Pengabdian Multidisiplin

Berdasarkan biosintesinya, metabolit sekunder yang dihasilkan tumbuhan dapat dikelompokkan menjadi alkaloid, terpenoid, dan flavonoid. Metabolit sekunder yang terdapat pada tumbuhan terkadang digunakan sebagai senyawa penanda untuk takson tumbuhan tertentu. Sebagai contoh Andrographolide merupakan senyawa marker dari tanaman Andrographis paniculata (He et al., 2003). Genus Pluchea mengandung jenis eudesmane, sesquiter-penoid, monoterpen, glikosida lignan, triterpenoid, dan flavonoid (Sharma and Goyal, 2011).

Berbagai senyawa aromatik seperti senyawa tiopenes ditemukan pada kelompok Asteraceae termasuk Pluchea (Ibrahim et al., 2016). Thiophenes merupakan kelompok senyawa aromatik berdasarkan pada cincin beranggota lima terdiri dari satu sulfur dan empat atom karbon. Senyawa tiofena memiliki sifat biologis yang luas seperti antimikroba, anti virus, inhibitor HIV-1 protease, anti leishmania, nematisidal, insektisidal, fototoksik dan anti kanker (Ibrahim et al., 2016). PI dideteksi sebanyak 66 senyawa volatil oil dan mempresentasikan 46,3\% dari keselurhan essential oilnya yang terdiri dari senyawa siklik yang tidak jenuh, senyawa hidrokarbon alkohol (6,16\%), hidrokarbon keton (3,49\%), hidrokarbon aromatik (2,05\%), hidrokarbon aldehid $(1,79 \%)$, hidrokarbon alifatik yang tidak jenuh $(1,35 \%)$, ester $(0,08 \%)$, sulfoxides $(0,06 \%)$, dan hidrokarbon heterosiklik $(0,05 \%)$. (10S,11S)-himachala-3(12)-4-diene $\quad(17,13 \%) \quad$ merupakan pembangun senyawa volatil oil menjadi tertinggi pada PI (Widyawati et al., 2012). PI mengandung sejumlah senyawa fenolik seperti turunan asam caffeoylquinat. Daun PI secara tradisional digunakan sebagai teh herbal untuk tonik saraf (Kongkiatpaiboon et al., 2018).

Kandungan metabolit sekunder PI bervariasi tergantung metode yang digunakan untuk ekstraksi. Beberapa metode ekstraksi yang digunakan antara lain maserasi, decoction, digestion, soxhlet extraction, dan ultrasound. Daun PI mengandung turunan caffeoylquinic acid seperti: viz. 3-Ocaffeoylquinic acid, 4-O-caffeoylquinic acid, 5-O caf-feoylquinic acid, 3,4-Odicaffeoylquinic acid, 3,5-O-dicaffeoylquinic acid, dan 4,5-O-dicaffeoyl-quinic acidin Ekstraksi daun PI dengan cara ultrasound dengan etanol 50\% menghasilkan senyawa turunan asam caffeoylquinic paling tinggi (Kongkiatpaiboon et al., 2018). Daun PI yang diperoleh dari berbagai daerah maupun pasar di Thiland mengandung asam klorogenat, asam 3,4-O-dicaffeoylquinic, dan asam 3,5O-dicaffeoylquinic yang bervariasi dan kandungan yang diperjual lebih tinggi dari yang diperoleh diambil dari daerah lainnya (Chewchinda and Vongsak, 2018). Kandungan asam klorogenat, asam 3,4-Odicaffeoylquinic, dan asam 3,5-Odicaffeoylquinic dari tujuh provinsi di Thailan tidak terdeteksi sedangkan dalam produk komersial senyawa tersebut ditemukan dengan kadar 0,59 $\pm 0,03-2,17 \pm$ $0,05 \% \mathrm{w} / \mathrm{w} ; 0,53 \pm 0,04-3,77 \pm 0,03 \% \mathrm{w} / \mathrm{w}$; dan $0,88 \pm 0,05-4,72 \pm 0,10 \% \mathrm{w} / \mathrm{w}$, secara berurtan. PI yang ditanam di daerah pesisir di tanah salin memiliki konsentrasi senyawa aktifnya dan meningkatkan kualitas obatnya (Chewchinda dan Vongsak, 2018). Ekstrak etanol-air daun PI mengandung senyawa thiophenes, (300R)-pluthiophenol, (300R)pluthiophenol-400-acetate, 300-ethoxy(300S)-pluthiophenol, 300-ethoxy-(300S)pluthiophenol-400-acetate, bersama dengan 
dua puluh lima (Gambar 2) (Ruan et al., 2018).

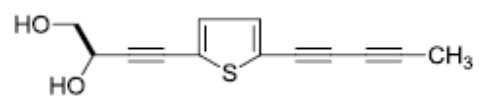

(3"R)-pluthiophenol

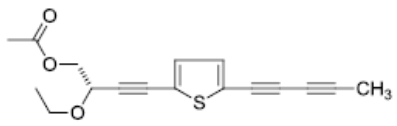

3"-ethoxy-(3"S)-

pluthiophenol-4"-acetate<smiles>COc1cc(/C=C/C=O)ccc1O</smiles>

trans-coniferyl aldehyde

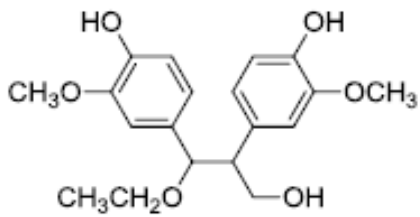

erythro-2,3-bis(4-hydroxy-3methoxyphenyl)-3ethoxypropan-1-ol

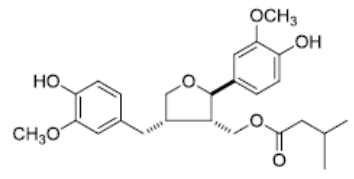

(+)-9'-isovaleryllariciresinol

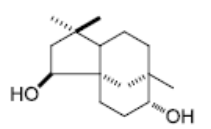

clovane-2 $\alpha, 9 \beta$-diol

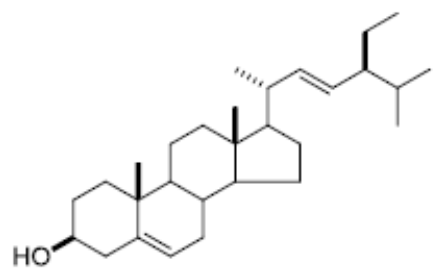

stigmasterol

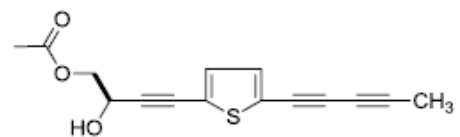

(3"R)-pluthiophenol-4"acetate

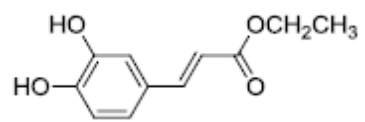

ethyl caffeate<smiles>O=c1ccc2cc(O)c(O)cc2o1</smiles>

esculetin

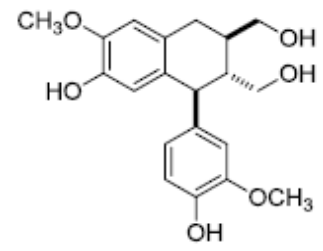

(+)-isolariciresinol

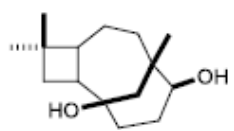

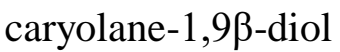<smiles>CC(C)(O)C1C[C@H]2CCCC=C2CC1O</smiles>

valenc-1(10)-ene-8,11-diol<smiles>COC(=O)CCCCCCCCO</smiles>

methyl 9-hydroxynonanoate

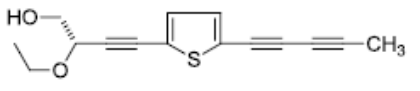

3"-ethoxy-(3"S)-

pluthiophenol<smiles>COc1cc(C(=O)C(O)CO)ccc1O</smiles>

2,3-dihydroxy-1-(4-

hydroxy-3 methoxyphenyl)

-propan-1-one<smiles>CCOC(c1ccc(O)c(OC)c1)C(CO)c1ccc(O)c(OC)c1</smiles>

threo-2,3-bis(4-hydroxy-3-

methoxyphenyl)-3-

ethoxypropan-1-ol

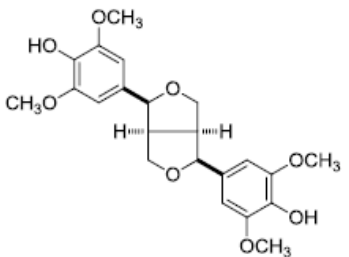

(-)-(7S, 7'S, 8R, 8'R)-4,4'-

dihydroxy-3,3',5,5'-

pentamethoxy-7,9':7',9-

diepoxylignane

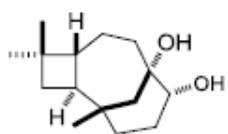

(8R,9R)-isocaryolane-8,9-

diol

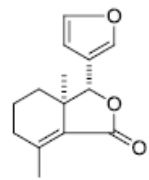

fraxinellone

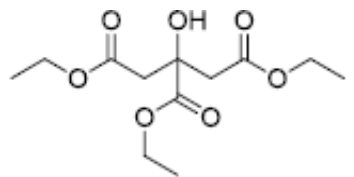

Triethyl citrate 
<smiles>CCCC(O)C(O)C=CC(O)CCCCCCCC(=O)O</smiles>

9,12,13-trihydroxyoctadeca10(E),15(Z)-dienoic acid

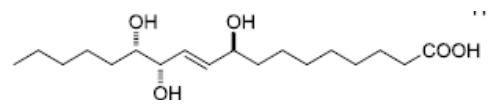

pinellic acid

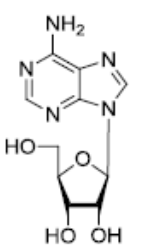

adenosine

Gambar 2. Struktur kimia senya bioaktif dari Pluchea indica yang diekstrak dengan menggunakan etanol-air 70\% dari bagian taruk (Ruan et al., 2018).

\section{MANFAAT DAN BIOAKTIVITAS}

Pluchea indica telah lama digunakan dalam pengobatan tradisional, minuman kesehatan dan juga sebagai sayuran terutama masyarakat yang tinggal di Asia Tenggara sperti Indonesia, Malaysia, Vietnan, Thailand dan Cambodia. Di Malaysia, Indochina, dan India daun PI digunakan untuk penurun panas dan untuk mengeluarkan keringat. Di Indonesia dan Malaysia digunakan untuk mengatasi gangguan lambung dan untuk meningkatkan air susu ibu dan obat batuk. PI juga digunakan sebagai sayuran dengan cara dilalap atau dimasak yaitu bagian daun muda, pucuk maupun bunga (Raharjo dan Horsten, 2002). Di Vietnam dan Cambodia daun PI digunakan sebagai teh atau daun dengan pucuk digunakan sebagai campuran dengan alkohol untuk mengatasi lumbago (Raharjo dan Horsten, 2002). Pada pengobatan tradisional Thailand, daun PI digunakan untuk diabetes mellitus, tumor, hipertensi, sistitis, dan luka (Chewchinda dan Vongsak, 2018). Teh herbal PC telah dikomersialkan di Thailand sebagai minuman untuk meningkatkan kesehatan (Chewchinda dan Vongsak, 2018). PI di Thailand digunakan sebagai obat tradisional, digunakan untuk pengobatan batu ginjal (batang), wasir, radang, sakit pinggang, dan keputihan (Suriyaphan, 2014). PI merupakan salah satu tumbuhan obat yang digunakan sebagai lumbago, ulcer, tuberculosis dan inflammasi (Kao et al., 2015). PI memiliki aktivitas sebagai anti fungi. PI digunakan sebagai obat batuk, demam dan aroma tubuh, meningkatkan nafsu makan dan membantu pencernaan (Putri dan Habib 2007). Walaupun banyak manfaat PI secara etnobotani, namun hasil penelitian menunjukkan bioaktivitas PI sebagai anti mikroba, antioksidan, anti fertilitas, anti diabetes mellitus, anti inflamantori, analgesik, anti kanker dan obat luka.

\subsection{Anti Mikroba}

Senyawa anti mikroba merupakan senyawa yang berfungsi menghambat atau mematikan mikroorganisme. Berbagai jenis jamur mikroskopis dan bakteri mengakibatkan berbagai jenis penyakit pada manusia termasuk gangguan pada rongga mulut seperti karies gigi. Streptococcus mutans merupakan bakteri yang paling umum penyebab plak gigi dan penyebab utama dari karies gigi (Nahak et al., 2011). Salah satu upaya yang dilakukan untuk mengatasi karies gigi adalah dengan cara berkumur-kumur menggunakan ekstrak daun PI. Hasil penelitian menunjukkan bahwa tidak ada perbedaaan efektivitas kumur-kumur ekstrak etanol daun PI dengan konsentrasi 10\%, 20\% dan $30 \%$ untuk menurunkan jumlah koloni Streptococcus sp. pada plak gigi dibandingkan dengan kontrol positif dengan nilai $p=0,31$ atau $p>0,05$ klorheksidin (Nahak et al., 2011). Ekstrak etanol daun PI maupun kontrol positif dengan menggunakan klorheksidin, sama-sama efektif untuk 
VIVABIO

Jurnal Pengabdian Multidisiplin

menurunkan jumlah koloni Streptococcus sp. pada plak gigi (Nahak et al., 2011).

Daun Pluchea mengandung flavonoid, essential oil, dan saponin yang memiliki aktivitas antifungi (Putri dan Habib 2007). Konsentrasi hambat minimum/ minimal inhibitory concentrations (MIC) dan minimal fungicidal concentrations (MFC) ekstrak etanol daun PI dan ketoconazole ditentukan dengan menggunakan metode macro-broth dilution, sedangkan MFC ditentukan dengan kultur sel pada plate SDA (sabaroud dextrose agar). MIC dan MFC ekstrak etnaol daun PI sebesar 3,125\%, ketoconazole sebesar 6,25 $\%$. Ekstrak etanol daun PI memiliki aktivitas sebagai anti fungi lebih tinggi melawan Malassezia sp. dibandingkan dengan ketoconazole (Putri dan Habib, 2007).

\subsection{Antioksidan}

Penelitian tumbuhan sebagai antioksidan semakin banyak dilakukan, hal tersebut berhubungan dengan kenyataan bahwa radikal bebas merupakan salah satu pemicu dari berbagai penyakit berat seperti diabetes mellitus. Bioaktivitas PI sebagai antiokasidan telah dilaporkan oleh Widyawati et al. (2013) dan Rahman et al. (2014). PI mengandung essensial oil dan memiliki aktivitas sebagai antioksidan yang diuji dengan menggunakan kemampuan pemulungan (scavenge) DPPH (1,1-diphenyl2-picrylhidrazyl) radikal bebas dan menghambat peroksidasi lipid. Aktivitas pemulungan DPPH dari essential oil pada daun PI lebih rendah dari O. basilicum, namun sebaliknya aktivitas lipid peroksidasi daun PI lebih tinggi dibandingkan $O$. basilicum (Widyawati et al., 2013). Ekstrak daun PI memiliki aktivitas antioksidan yang sangat tinggi sekitar 7 kali dibandingkan dengan asam askorbat (Rahman et al., 2014).
Antioksidan fenolik dihasilkan dari proses metabolisme sekunder tumbuhan dan aktivitas antioksidan terutama berhubungan dengan sifat redoks, struktur kimia yang dapat berperan penting dalam pengambilan (chelating) metal trasisional, penghambatan lipoxygenase dan pemulungan (scavenging) radikal bebas (Al-Reza et al., 2010). Ekstrak metanol daun PI memiliki aktivitas menangkap radikal bebas DPPH, superoksida, hidroksil dan hidrogen peroksida, mereduksi ion besi, mengkelat ion besi dan hemoglobin $(\mathrm{Hb})$ dan menghambat pemucatan asam linoleat- $\beta$-karoten. Fraksi ekstrak metanol, etil asetat, air, dan n-butanol daun PI berpotensi menangkap radikal bebas DPPH. Ekstrak metanol daun PI mempunyai kadar fenolik total dan kekuatan reduksi tertinggi lebih berpotensi menangkap radikal superoksida, mereduksi ion besi dan menghambat pemucatan asam linoleat- $\beta$ karoten, sedangkan fraksi etil asetat mempunyai aktivitas antioksidan berdasarkan kemampuan menangkap radikal superok-sida, mereduksi ion besi, mengkelat ion besi dan hemoglobin (Widyawati et al., 2012).

\subsection{Anti Fertilitas}

Daun PI memiliki aktivitas menghambat spermatogenesis. Flavonoid dapat menghambat enzim aromatase yang berfungsi mengkatalisis perubahan androgen ke dalam estrogen sehingga kadar hormon testosterone meningkat. Konsentrasi yang tinggi dari testosterone akan mempengaruhi pada umpan balik (feedback) ke pituitari, sehingga tidak melepaskan folicle stimulating hormone (FSH) dan luteinizing hormone (LH), sehingga dapat menghambat spermatogenesis. Pemberian ekstrak daun PI pada tikus dengan kadar 1,4; 2,8; dan 5,6 $\mathrm{mg} / \mathrm{g}$ berat badan selama 10 hari menurunkan jumlah spermatid dengan efek yang berbeda- 
VIVABIO

Jurnal Pengabdian Multidisiplin

beda. Pada dosis $5,6 \mathrm{mg} / \mathrm{g}$ menurunkan jumlah spermatid yang paling tinggi (Suyatmi et al., 2010).

Pemberian tanin PI dapat mempengaruhi tingkat asam glutamat dalam air mani tikus putih jantan (Susetyarini et al., 2018). Pemberian tannin PI mempenga-ruhi tingkat asam glutamat dalam semen tikus putih jantan $(\mathrm{p}<0,05)$. Tikus putih jantan pada kelompok kontrol memiliki rata-rata 1 547,48 mg (100 g) $)^{-1}$ kadar asam glutamat; sedangkan tikus putih jantan dalam kelompok eksperimen (setelah pemberian tannin PI) menunjukkan penurunan kadar asam glutamat $\left(1.494,43 \mathrm{mg}(100 \mathrm{~g})^{-1}\right.$ hingga $1.341,40 \mathrm{mg}$ $\left.(100 \mathrm{~g})^{-1}\right)$. Level tinggi dan rendah dari asam glutamat menentukan kualitas spermatozoa (Susetyarini et al., 2018).

\subsection{Anti Inflamantori}

Inflamasi atau yang disebut juga sebagai peradangan merupakan salah satu cara tubuh untuk menghilangkan rangsangan berbahaya termasuk sel-sel yang rusak atau serangan mikroorganisme patogen. Ekstrak etanol daun PI memiliki aktivitas sebagai anti-inflammatori dan antinociceptive (Roslida et al., 2008) yang diuji dengan tes menggunakan model carrageenan-induced oedema dan test menggeliat (writhing test) asam asetat. Ekstrak daun PI menunjukkan aktivitas yang dan aktivitasnya tergantung dosis dan signifikan ketika dosis $300 \mathrm{mg} / \mathrm{kg}$ yang diberikan secara oral. Ekstrak daun PI ketika diberikan secara oral pada dosis 10, 30, 100, dan $300 \mathrm{mg} / \mathrm{kg}$ menghasilkan penghambatan signifikan pada konstriksi abdominal constriction yang diinduksi dengan $0,6 \%(\mathrm{v} / \mathrm{v})$ asam asetat (Roslida et al., 2008).

\subsection{Anti Diabetes Mellitus}

Diabetes mellitus merupakan gangguan metabolisme tubuh yang mengakibatkan kadar glukosa darah di atas normal atau disebut juga hiperglikemia. Hiperglikemia dapat memicu berbagai penyakit komplikasi kronik seperti stroke. Werdani dan Widyawati (2017) melaporkan bahwa teh daun PI sebagai minuman kesehatan memiliki efek sebagai antidiabetes dan telah diuji pada 21 pasien penderita diabetes mellitus dan memberi efek yang signifikan. Potensi efek antidiabetes teh daun PI ketika dikomsumsi secara reguler terbukti memiliki aktivitas sebaga antioksidan (Werdani dan Widyawati, 2017).

\subsection{Analgesik}

Analgesik merupakan senyawa yang berfungsi mengurangi rasa sakit. Ekstrak daun PI memiliki aktivitas sebagai analgesik dengan dosis $150 \mathrm{mg} / \mathrm{kg} \mathrm{BB}, 300 \mathrm{mg} / \mathrm{kg} \mathrm{BB}$, dan $600 \mathrm{mg} / \mathrm{kg} \mathrm{BB}$, namun lebih rendah dari parasetamol (Sibarani et al., 2013). Pengujian efek analgesik dilakukan dengan memberikan rangsangan nyeri pada hewan uji, berupa rangsangan panas dengan suhu $55^{\circ} \mathrm{C}$. Hasil penelitian menunjukkan jumlah respon terhadap rangsang nyeri pada kelompok mencit yang diberi ekstrak daun PI mulai menurun pada menit ke-30 dan terus memberikan efek pada menit ke-60 dan menurun pada menit ke-90 efek (Sibarani et al., 2013).

\subsection{Anti Obesitas}

Obesitas dan hyperlipidemia merupakan masalah kesehatan yang masih banyak ditemukan di dunia. Teh daun PI banyak digunakan sebagai minuman kesehatan dengan berbagai indikasi penyakit termasuk obesitas. Daun PI dapat menghambat aktivitas adipogenesis sel 3T3-L1 dan enzim lipase pankreas (Sirichaiwetchakoon et al., 2018). Viabilitas sel 3T3-L1 tidak menurun secara signifikan setelah terpapar $200-1000$ $\mu \mathrm{g} \mathrm{mL}^{-1}$ daun PI dibandingkan dengan 


\section{VIV ABIO}

Jurnal Pengabdian Multidisiplin

kontrol $(p>0,05)$. Ekstrak daun PI 750 $1000 \mu \mathrm{g} \mathrm{mL}^{-1}$ menunjukkan penghambatan akumulasi lipida dibandingkan dengan kontrol $(p<0,05)$. Daun PI pada konsentrasi $250-1000 \mu \mathrm{g} \mathrm{mL} \mathrm{men}^{-1}$ menghambat aktivitas lipase secara signifikan dibandingkan dengan kontrol ( $p<0.05)$. Hasil FTIR menunjukkan bahwa area terintegrasi dari lipid, protein, asam nukleat, glikogen, dan karbohidrat dari daun PI yang diobati Adiposit 3T3-L1 secara signifikan lebih rendah daripada adiposit 3T3-L1 yang tidak diobati $(p<0.05)$. Daun PI tidak hanya mampu menghambat lipid dan akumulasi karbohidrat dalam adiposit tetapi juga memiliki potensi untuk menghambat aktivitas lipase pankreas. Lebih lanjut menjadi suplemen herbal penurun lipid baru untuk pengelolaannya kelebihan berat badan atau obesitas (Sirichaiwetchakoon et al., 2018). Penambahan daun PI pada makanan ayam broiler akan mempengaruhi kandungan kolesterol daging. Ransum ayam yang dicampur dengan $2 \%, 4 \%, 6 \%$ dan $8 \%$ daun PI mempengaruhi kadar kolesterol daging secara signifikan dan berat tubuh, perolehan berat tubuh, pengembailan makanan dan air menurun sejalan dengan makin meningkatnya konsentrasi daun PI (Sadarman et al., 2011).

\subsection{Anti Kanker}

Ekstrak air dan alkohol daun PI menunjukkan aktivitas tinggi dalam menghambat oksidasi lipid, pemulungan radikal bebas, dan reduksi ion besi (Suriyaphan, 2014). Ekstrak air daun PI berpotensi sebagai agen anti-kanker karena kemampuannya untuk menghambat proliferasi dan migrasi sel kanker ganas glioma otak manusia (GBM8401) dan kanker sel serviks manusia (sel HeLa) (Suriyaphan, 2014). Ekstrak etanol akar PI memiliki aktivitas sebagai anti kanker yang sangat kuat pada sel nasopharyngeal carcinoma (NPC) manusia tergantung waktu dan dosis. Ekstrak etanol akar PI meningkatkan sel pada fase sub-G1 dan pemanjangan fragmentasi DNA tergantung dosis yang menunjukkan peningkatan apostosis pada sel NPC. Proses apostosis dipicu oleh ekatrak akar PI melibatkan pengaturan protein Bax proapoptosis dan regulasi protein $\mathrm{Bcl}-2$ antiapoptosis, akibatnya meningkatkan rasio kadar protein Bax/Bcl-2 (Kao et al., 2015).

\subsection{Obat Luka}

Luka merupakan infeksi fisik yang mengakibatkan kulit terbuka dan rusak. Luka pada bagian oral mungkin dapat diakibatkan oleh kegiatan fisik, senyawa kimia, aktivitas mekanik atau trauma human gingival fibroblast (HGF) (Rahman et al. 2014). Penyembuhan luka pada bagian mulut sering mengalami kendala karena adanya assosiasi berbagai mikroorganisme yang terdapat di mukos mulut sehingga penyembuhan berjalan lambat (Rahman et al., 2014). Tumbuhan yang digunakan untuk penyembuhan luka sudah banyak, namun berbeda dengan penyembuhan pada luka mulut. Ektrak daun (100 $\mu \mathrm{g} / \mathrm{mL})$ dari $M$. malabathricum, $P$. indica dan $P$. sarmento-sum menunjukkan sangat sedikit proliferasi yaitu sekitar $24.2 \%$, $13.4 \%$, dan $28.6 \%$ secara berurutan (Rahman et al., 2014).

\section{KESIMPULAN DAN SARAN}

Masyarakat lokal Desa Sindang Jaya telah lama memanfaatkan Pluchea indica sebagai lalaban dan obat. Berbagai senyawa aromatik ditemukan pada PI seperti thiophenes, asam klorogenat, asam 3,4-O-dicaffeoylqui-nic, dan asam 3,5-O-dicaffeoylquinic. Senyawa tiofena memiliki sifat biologis yang luas seperti antimikroba, anti virus, inhibitor HIV-1 protease, anti leishmania, nematisidal, insektisidal, fototoksik dan anti kanker. Bioaktivitas PI 
VIVABIO

Jurnal Pengabdian Multidisiplin

sebagai anti mikroba, antioksidan, anti fertilitas, anti diabetes mellitus, anti inflamantori, analgesik, anti kanker dan obat luka.

\section{UCAPAN TERIMA KASIH}

Saya mengucapkan terima kasih kepada Masyarakat Desa Sindang Jaya yang memberi informasi pemanfaatan PI dan juga Universitas Kristena Indonesia yang menberi dana dalam pelaksanaan pengabdian masyarakat ini.

\section{DAFTAR PUSTAKA}

Ahemd SA and EM Kamel. 2013. Phenolic constituents and biological activity of the genus pluchea. Der Pharma Chemica 5(5): 109-114.

Al-Reza SM, A Rahman , C Young-Su, SC Kang. 2010. Chemical composition and antioxidant activity of essential oil and organic extracts of Cestrum nocturnum L. Jeobp 13: 615-624.

Balunas MJ, AD Kinghorn. 2005. Microtubules as a target for anticancer drugs. Life Sciences 78: 431 - 441.

Chewchindaa S, B Vongsak. 2018. Simultaneous HPTLC quantification of three caffeoylquinic acids inPluchea indica leaves and their commercial products in Thailand. Revista Brasileira de Farmacognosia $\mathrm{xxx}$ : $\mathrm{xxx}-\mathrm{xxx}$.

He X, J Li, H Gao, F Qiu, K Hu, X Cui, X Yao. 2003. Identification of a rare sulfonic acid metabolite of andrographolide in rats. Drug Metabolism and Disposition 31(8): 983-985.

Ibrahim SRM, HM Abdallah, AM ElHalawany, GA Mohamed. 2016. Naturally occurring thiophenes: isolation, purification, structural elucidation, and evaluation of bioactivities. Phytochem Rev 15: 197220.

Kao CL, J Cho, YZ Lee, YB Cheng, CY Chien, CF Hwang, YR Hong, CN Tseng, CL Cho. 2015. Ethanolic extracts of Pluchea indica induce apoptosis and antiproliferation effects in human nasopharyngeal carcinoma cells. Molecules 20: 11508-11523.

Kongkiatpaiboon, S, S Chewchinda, B Vongsak. 2018. Optimization of extraction method and HPLC analysis of six caffeoylquinic acids in Pluchea indica leaves from different provenances in Thailand. Revista Brasileira de Farmacognosia 28: 145150.

Nahak MM, R Tedjasulaksana, NN Sumerti. 2015. Efektivitas kumur ekstrak etanol daun beluntas (Pluchea indica. L.) untuk menurunkan jumlah koloni Streptococcus sp. pada plak gigi. Jurnal Skala Husada 12(1): 56-64.

Putri RK, I Habib. 2007. Daya antifungi ekstrak etanol daun beluntas (Pluchea indica, L.) terhadap Malassezia Sp. secara in vitro. Mutiara Medika Edisi Khusus 7(1): 07-17.

Rahman MRA, FA Razak, MM Bakri. 2014. Evaluation of wound closure activity of Nigella sativa, Melastoma malabathricum, Pluchea indica, and Piper sarmentosum extracts on scratched monolayer of human gingival fibroblasts. Hindawi Publishing Corporation Evidence-Based Complementary and Alternative Medicine. Volume 2014, Article ID 190342, 9 pages. http://dx.doi.org/10.1155/2014/190342 
VIVABIO

Jurnal Pengabdian Multidisiplin

Raharjo I, SFAJ Horsten. 2002. Pluchea indica in: Plant Resources of South East Asia No 12 (2). JLCH van Valkenburg and $\mathrm{N}$ Bunyapraphatsara. Bogor Indonesia: 441-443.

Roslida AH, AK Erazuliana, A Zuraini. 2008. Anti-inflammatory and antinociceptive activities of the ethanolic extract of Pluchea indica (L) less leaf. Pharmacologyonline 2: 349-360.

Ruan Y, Z Li, J Yan, P Huang, H Yu, L Han, Y Zhang, T Wang. 2018. Bioactive constituents from the aerial parts of Pluchea indica Less. Molecules 23: 111.

Sharma SK, N Goyal. 2011. Biological studies of the plants from genus Pluchea. Annals of Biological Research 2(3) : 25-34.

Sibarani VR, PM Wowor, H Awaloei. 2013. Uji efek analgesik ekstrak daun beluntas (Pluchea indica (L.) Less.) pada mencit (Mus musculus) Jurnal eBiomedik (eBM), 1(1): 621-628.

Silalahi M. 2019. Keanekaragaman tumbuhan bermanfaat di pekarangan oleh Etnis Sunda Di Desa Sindang Jaya Kabupaten Cianjur Jawa Barat. Jurnal Pendidikan Matematika Dan IPA 10(1): 88-104.

Sirichaiwetchakoon K, GM Lowe, K Thumanu, G Eumkeb. 2018. The effect of Pluchea indica (L.) Less. Tea on adipogenesis in 3T3-L1 Adipocytes and lipase activity. Hindawi EvidenceBased Complementary and Alternative Medicine Volume 2018, Article ID 4108787, 13 pages

Susetyarinia RE. 2015. The level of glutamic acid in the semen of male white rat (Ratus norwegicus) after being treated with tannin of Pluchea indica. Procedia Chemistry 14: 152-156.

Sudarman A, Sumiati, SH Solikhah. 2011. Performance and meat cholesterol content of broiler chickens fed Pluchea indica $\mathrm{L}$. leaf meal reared under stress condition. Media Peternakan: 64-68

Suyatmi AN, EL Suparyanti. 2010. Effect of beluntas (Pluchea indica) leaf extract on mice spermatogenesis. Biofarmasi 8: 47-51.

Suriyaphan O. 2014. Nutrition, health benefits and applications of Pluchea indica (L.) Less leaves. Mahidol University Journal of Pharmaceutical Sciences 41(4): 1-10.

Taiz, L. \& E. Zeiger. Plant Physiology. Sinauer Associates, Inc, Sunderland: $\mathrm{xxvi}+764 \mathrm{hlm}$.

Werdani YDW, PS Widyawati. 2017. Antidiabetic effect of Pluchea indica Less tea as a functional beverage in diabetic patients. Advances in Social Science, Education and Humanities Research (ASSEHR), volume 98. 1st International Conference Postgraduate School Universitas Airlangga: Implementation of Climate Change Agreement to Meet Sustainable Development Goals (ICPSUAS 2017): $1-4$

Widyawati PS, CH Wijaya, PS Hardjosworo, D Sajuthi. 2013. Volatile compounds of Pluchea indica Less and Ocimum basillicum Linn essential oil and potency as antioxidant. Hayati Journal of Biosciences 20(3): 117-126.

Widyawati PS, H Wijaya, PS Harjosworo, D Sajuthi. 2012. Aktivitas antioksidan berbagai fraksi dan ekstrak metanolik daun beluntas (Pluchea indica Less). Agritech 32( 3): 249-257. 